\title{
EFEKTIVITAS KEBIJAKAN RELOKASI ANGGARAN PROGRAM PENANGGULANGAN COVID-19 DI DESA BENUA BARU
}

\section{THE EFFECTIVENESS OF BUDGET RELOCATION POLICY OF THE COVID-19 MANAGEMENT PROGRAM IN THE VILLAGE OF BENUA BARU}

\author{
Adi Sucipto $^{1}$; Musriadi $^{2}$
}

Fakultas Ilmu Sosial dan Ilmu Politik, Universitas Kutai Kartanegara, Tenggarong 1,2 e-mail: adisucipt59@gmail.com@gmail.com ${ }^{1}$

\begin{abstract}
Throughout 2020, health issues became the main focus compared to other issues because at the end of 2019 the SARS-Cov-2 Corona Virus was discovered and reported to have spread in Wuhan, China. Precisely on Monday, March 2, 2020, Indonesia first confirmed the case of Covid-19. This case is increasing and spreading rapidly throughout Indonesia. This paper aims to explore more deeply about the role taken by the Village Government in the Covid-19 response policy, starting from changes in the target of village development planning and the Covid-19 prevention program carried out by the Village government. The method used is qualitative with descriptive analysis model.

The results obtained are that in the process of shifting the budget for the Covid-19 response in Benua Baru Village, it still involves community participation through screening aspirations and musdes, while still carrying out health protocols. One of the adjustments to the Village Fund budget in order to fund Covid-19 prevention programs is through reducing celebration funds and other infrastructure development activities that are adjusted to priority needs. The Benua Baru village government implemented several programs based on regulatory directions and circulars of the Kutai Kartanegara Regent in preventing Covid-19, namely: 1) Formation of the Covid-19 Task Force Team; 2) Making Isolation Room; 3) Distribution of Masks; 4) Disinfectant Spraying; 5) Provision of Hand Sanitizer and Hand Soap; and 6) Direct Cash Assistance (BLT).
\end{abstract}

Keywords: Effectiveness, Policy, Budget Relocation, Covid-19 


\section{Abstrak}

Sepanjang 2020, isu kesehatan menjadi sorotan utama dibandingkan dengan isu-isu lainnya lantaran pada akhir 2019 Virus Corona SARS-Cov2 ditemukan dan dilaporkan penyebarannya di Wuhan China. Tepatnya pada Senin 2 Maret 2020 Indonesia pertama kali mengkonfirmasi kasus Covid-19. Kasus ini meningkat dan menyebar dengan cepat di seluruh wilayah Indonesia. Tulisan ini bertujuan untuk mengupas lebih dalam tentang peran yang diambil Pemerintah Desa dalam kebijakan penanggulangan covid-19, mulai dari perubahan target perencanaan pembangunan Desa dan program penanggulangan Covid-19 yang dilakukan pemerintah Desa. Metode yang digunakan adalah kualitatif dengan model analisis deskriptif.

Hasil yang diperoleh yaitu dalam proses pergeseran anggaran untuk penanggulangan Covid-19 di Desa Benua Baru tetap melibatkan partisipasi masyarakat melalui penjaringan aspirasi dan musdes, dengan tetap menjalankan protokol kesehatan. Penyesuaian anggaran Dana Desa dalam rangka untuk mendanai program penanggulangan Covid-19 salah satunya melalui pengurangan dana perayaan dan kegiatan pembangunan infrastruktur lainnya yang disesuaikan dengan perioritas kebutuhan. Pemerintah desa Benua Baru menerapkan beberapa program berdasarkan arahan regulasi dan surat edaran Bupati Kutai Kartanegara dalam pencegahan Covid-19, yaitu : 1) Pembentukan Tim Satgas Covid-19;2) Pembuatan Ruang Isolasi; 3) Pembagian Masker; 4) Penyemprotan Disinfektan; 5) Penyediaan Handsanitizer dan Hand Soap; dan 6) Bantuan Langsung Tunai (BLT).

Kata kunci: Efektivitas, Kebijakan, Relokasi Anggaran, Covid-19

\section{A. PENDAHULUAN}

Sepanjang 2020, isu kesehatan menjadi sorotan utama dibandingkan dengan isuisu lainnya lantaran pada akhir 2019 Virus Corona SARS-Cov-2 ditemukan dan dilaporkan penyebarannya di Wuhan China. Dan mulai ditetapkan sebagai pandemic oleh World Health Organization (WHO) pada maret 2020 dikarenakan tingkat penyebarannya tidak terbatas pada satu wilayah geografis, namun menyeluruh hingga ke seluruh negara (Junita, 2020). Presiden Joko Widodo mengumumkan ada dua warga Indonesia positif terjangkit virus Corona, tepatnya pada Senin 2 Maret 2020 Indonesia pertama kali mengkonfirmasi kasus Covid-19. Kasus ini meningkat dan menyebar dengan cepat di seluruh wilayah Indonesia. Kasus positif Covid-19 di Indonesia terkonfirmasi mencapai 8.607 kasus dan menyebar di 34 provinsi dengan 
kasus terbanyak di DKI Jakarta (Tim detikcom, 2020). Tingginya tinggat penyebaran yang telah menjangkau keseluruh wilayah di Indonesia, membuat pemerintah menerbitkan Keputusan Presiden Nomor 11 Tahun 2020 tentang Penetapan Kedaruratan Kesehatan Masyarakat Corona Virus Disease 2019 (COVID-19). Kondisi ini secara langsung berdampak pada aspek ekonomi, kesejahtaeraan, sosial, budaya, serta pertahanan dan keamanan masyarakat di Indonesia. Selain itu, pemerintah juga mengeluarkan Keputusan Presiden Nomor 12 Tahun 2020 tentang Penetapan Bencana Non-alam, penyebaran Corona Virus Disease 2019 (COVID-19) Sebagai Bencana Nasional.

Untuk mempercepat penanganan wabah tersebut, melalui Surat Edaran Kemendes PDTT nomor 8 Tahun 2020 menghimbau seluruh pemerintah Desa di Indonesia melakukan penyesuaikan APBDes. Hal ini dikarenakan penggunaan Dana Desa ditahun 2020 diperioritaskan untuk Desa Tanggap Covid-19 dan Penegasan Padat Karya Tunai Desa, dalam rangka mendorong desa mencegah terjadinya krisis ekonomi dan kesehatan di kawasan perdesaan. Penyesuaian anggaran tersebut tentunya menuai banyak dampak dan tantangan dalam proses penyesuaian anggaran dikarenakan perencanaan anggaran yang telah ditetapkan harus dilakukan perubahan. Disisi lain Pemerintah Desa memiliki peran yang sangat penting dalam pengambilan kebijakan penyesuaian Dana Desa, hal ini untuk menjaga stabilitas ekonomi dan kesejateraan masyarakat di masa pandemic covid-19. Berdasarkan kondisi diatas, tulisan ini bertujuan untuk mengupas lebih dalam tentang peran yang diambil Pemerintah Desa dalam kebijakan penanggulangan covid19, mulai dari perubahan target perencanaan pembangunan Desa dan program penanggulangan Covid-19 yang dilakukan pemerintah Desa.

\section{B. METODE PENELITIAN}

Penelitian ini menggunakan metode kualitatif (Creswell, 2016), karena dengan penggunaan metode kualitatif dapat memberikan gambaran yang lebih mendalam tentang informasi di lapangan. Untuk mendeskripsikan hasil temuan lapangan, peneliti membingkainya dengan model analisis deskriptif. Teknik yang digunakan peneliti dalam pengumpulan data adalah studi kepustakaan dengan mengumpulkan data dan mempelajarinya sebagai sumber literatur, selain itu peneliti juga melakukan wawancara mendalam ke beberapa informan. Teknik analisisnya berdasarkan Miles dan Huberman (Gunawan, 2013), yang terdiri dari tiga alur kegiatan, yaitu reduksi data, penyajian data, dan penarikan kesimpulan atau verifikasi. 


\section{KERANGKA TEORI \\ Efektivitas Kebijakan Publik}

1) Kebijakan Publik

Kebijakan publik adalah respon pemerintah dalam pengambilan keputusan atau tindakan sebagai solusi permasalahan publik yang terjadi. Menurut Thomas $\mathrm{R}$ Dye dalam Pasolong (2010), mengemukakan bahwa kebijakan publik adalah keputusan otoritatif pemerintah untuk melakukan atau tidak melakukan suatu tindakan. Pada dasarnya, kebijakan publik meliputi semua tindakan pemerintah dan bukan semata-mata karena keinginan pejabat atau pemerintah saja sebagai hasil politik, akan tetapi harus aja tujuan untuk merespon permasalahan publik yang terjadi.

Dalam proses kebijakan publik terdapat beberapa tahapan yang masing-masing memiliki peran yang sangat krusial. Implementasi menjadi salah satu tahapan yang memiliki peran krusial. Implementasi kebijakan publik dikatakan krusial dikarenakan disana letak keberhasilan dari suatu kebijakan yang telah dirumuskan dengan matang. Tujuan dari kebijakan akan tercapai jika implementasi kebijakan sesuai dengan rencana yang direncanakan di awal. Ada beberapa poin penting yang harus dinilai dalam mengukur manfaat sebuah kebijakan, yaitu substansi, implementasi, serta dampak kebijakan (Cochran, 2005).

2) Efektivitas Kebijakan

Efektivitas dapat dimaknai sebagai kriteria pengamatan yang digunakan untuk memberi rekomendasi penyelesaian masalah yang ditimbulkan oleh suatu kebijakan. Hubert Graf dalam Lele (2016) berpendapat bahwa efisiensi dan efektivitas dipandang sebagai nilai kinerja pemerintah. Efektivitas keputusan dapat dinilai berdasarkan lima tipe kriteria utama, yaitu : efisiensi, kecukupan, perataan, responsivitas, dan kelayakan (Poister, dalam Dunn, 1998). Dalam pelaksanaan kebijakan publik, efektifitas diukur berdasarkan keberhasilan pencapaian tujuan dan sasaran yang telah ditetapkan dalam sebuah kebijakan. Konseptualisasi efektifitas yaitu terjadinya korelasi antara tujuan dan hasil yang dicapai dari sebuah kebijakan, dimana kerangka penilaian efektivitas mencakup tiga hal diantaranya yaitu input, proses, dan outcomes (Oberthür \& Groen, 2015). 


\section{Anggaran}

1) Konsep Anggaran

Anggaran merupakan rencana kerja dalam bentuk analisis angka atau yang sering dikenal dengan kuantitatif yang kemudian diukur dalam satuan moneter standar dan satuan ukuran lain yang mencakup jangka waktu satu tahun (Mulyadi, 20001). Pendapat tersebut semakin diperjelas berdasarkan pemaparan Rudianto (2009), yang menjelaskan ciri khusus yang membedakannya dengan hanya sekedar rencana, yaitu anggaran dinyatakan dalam satuan moneter; memiliki kurun waktu satu tahun; terkandung komitmen manajemen; usulan disetujui oleh pejabat yang lebih tinggi dari pelaksana anggaran; setelah disetujui anggaran hanya diubah jika ada keadaan khusus; dan jika terjadi penyimpangan/varians didalam pelaksanaannya, penyebab penyimpangan tersebut harus dianalisis.

Dalam setiap pelaksanaan pembangunan idealnya terdiri dari perencanaan dan penganggaran yang merupakan satu paket tahapan. Dalam sebuah perencanaan kegiatan pembangunan yang baik, dapat dikatakan berhasil jika mendapat dukungan anggaran yang sesuai. Sebab, anggaran merupakan instrument penting untuk mencapai tujuan bernegara. Dasar dalam setiap tahap perencanaan dan penganggaran adalah undang-undang yang diantaranya yaitu Undang-undang Nomor 17 tahun 2003 tentang keuangan Negara, Undang-undang Nomor 25 tahun 2004 tentang Sistem Perencanaan Pembangunan Nasional, Undangundang Nomor 23 tahun 2004 tentang pemerintahan daerah, dan Undang-undang Nomor 6 tahun 2014 tentang Desa, beserta peraturan turunannya seperti peraturan Menteri.

Didalam Undang-undang Nomor 6 tahun 2014 tentang Desa, mengamanatkan pemerintah desa untuk bisa mengakomodir segala kepentingan dan kebutuhan masyarakat desa dengan lebih baik. Karena desa bisa lebih mandiri untuk mengurus tata pemerintahannya, berbagai sumber daya alam yang dimiliki, termasuk didalamnya pengelolaan keuangan dan kekayaan milik desa, serta pemerataan pelaksanaan pembangunan diharapkan dapat meningkatkan kesejahteraan dan kualitas hidup masyarakat desa, sehingga permasalahan seperti kesenjangan antar wilayah, kemiskinan, dan masalah sosial budaya 
lainnya dapat diminimalisir (Badan Pengawasan Keuangan dan Pembangunan, 2015).

2) Relokasi Anggaran Program Penanggulangan Covid-19

Berdasarkan penjelasan diatas terkait anggaran dijelaskan bahwasannya setelah anggaran disetujui hanya dapat diubah jika ada keadaan khusus. Salah satu kondisi tersebut jika terjadi kondisi tak terduka seperti terjadi bencana, salah satu kondisinya seperti yang saat ini sedang dihadapi yaitu pandemi Covid-19. Untuk merespon pandemi Covid-19, pemerintah pusat menerbitkan PERPU Nomor 1 Tahun 2020 tentang Kebijakan Keuangan Negara dan Stabilitas Sistem Keuangan untuk Penanganan Pandemi Covid-19. Prioritas penggunaan Dana Desa tahun 2020 berdasarkan Peraturan Menteri Desa PDTT Nomor 11 Tahun 2019 juga mengalami perubahan melalui Permendesa DPTT Nomor 6 tahun 2020 hal ini menyesuaikan Perpres No.54 tahun 2020 tentang Perubahan Postur dan Rincian Anggaran Pendapatan dan Belanja Negara yang secara spesifik pada Pasal 2, ayat 2 dijelaskan bahwa anggaran dana desa dapat digunakan untuk jaring pengaman sosial di desa berupa BLT dan kegiatan penanganan wabah Covid-19.

\section{HASIL PENELITIAN}

\section{Perubahan Anggaran Dana Desa}

Pandemi Covid-19 memiliki pengaruh yang cukup besar bagi perencanaan pembangunan di daerah khususnya desa Benua Baru. Sejak dietapkannya kedaruratan kesehatan masyarakat karena pandemi Covid-19, membuat pemerintah pusat mendorong penggunaan Dana Desa untuk menanggulangi Covid-19. Untuk itu pemerintah pusat membuat payung hukum berupa Peraturan Pemerintah Pengganti Undang-undang (PERPU) Nomor 1 Tahun 2020, Perpres No. 54 Tahun 2020, PMK No.40/PMK.07/2020 tentang perubahan atas PMK No.205/PMK.07/2019, Peraturan Menteri Desa Nomor 6 Tahun 2020 tentang Perubahan atas Permendesa PDTT Nomor 11 Tahun 2019, Intruksi Menteri Dalam Negeri Nomor 3 Tahun 2020. Dengan adanya landasan regulasi tersebut, Dana Desa dapat digunakan untuk mendanai program penanggulangan Covid-19 yang meliputi pencegahan dan penanganan Covid-19, kegiatan pembangunan menggunakan tenaga masyarakat melalui Padat Karya Tunai Desa (PKTD), dan Bantuan pengaman sosial berupa Bantuan Langsung Tunai (BLT).

Benua Baru merupakan salah satu desa yang terletak di kecamatan Kota Bangun dengan Luas wilayah Desa $1.352 \mathrm{Km}^{2}$ dan jumlah penduduk keseluruhan sebesar 327 
jiwa. Menghadapi masa Pandemi Covid-19, Pemerintah Desa tentunya melakukan penyesuaian kembali APBDes yang telah tersusun untuk menyesuaikan regulasi yang berubah diantaranya berdasarkan prioritas penggunaan Dana Desa tahun 2020 yang semula melalui Peraturan Menteri Desa DPTT Nomor 11 Tahun 2019 menjadi Permendesa PDTT Nomor 6 Tahun 2020. Penyesuaian anggaran tersebut tentunya dilakukan melalui musyawarah, karena dalam setiap proses perencanaan, pemerintah Desa dan BPD selalu melibatkan partisipasi masyarakat melalui penjaringan aspirasi masyarakat. Masyarakat di desa Benua Baru memiliki partisipasi yang cukup tinggi dalam proses identifikasi permasalahan pembangunan. Dimasa pandemi Covid-19 pelaksanaan musyawarah tetap dilaksanakan dengan tetap menjaga protokol kesehatan.

Dana yang digunakan untuk menyelenggarakan beberapa kegiatan terkait penanganan dan pencegahan Covid-19 didasarkan pada kebutuhan pemakaian, bukan persentase langsung dari jumlah Dana Desa berdasarkan APBDes T.A 2020. Hampir sebagian besar dana yang dugunakan untuk program pencegahan dan penyebaran Covid-19 berasal dari Dana Desa, Pergeseran atau perubahan ini tentunya setelah berkonsultasi dengan pihak PMD Kecamatan dan Tenaga Pendamping Profesional (TPP) P3MD.

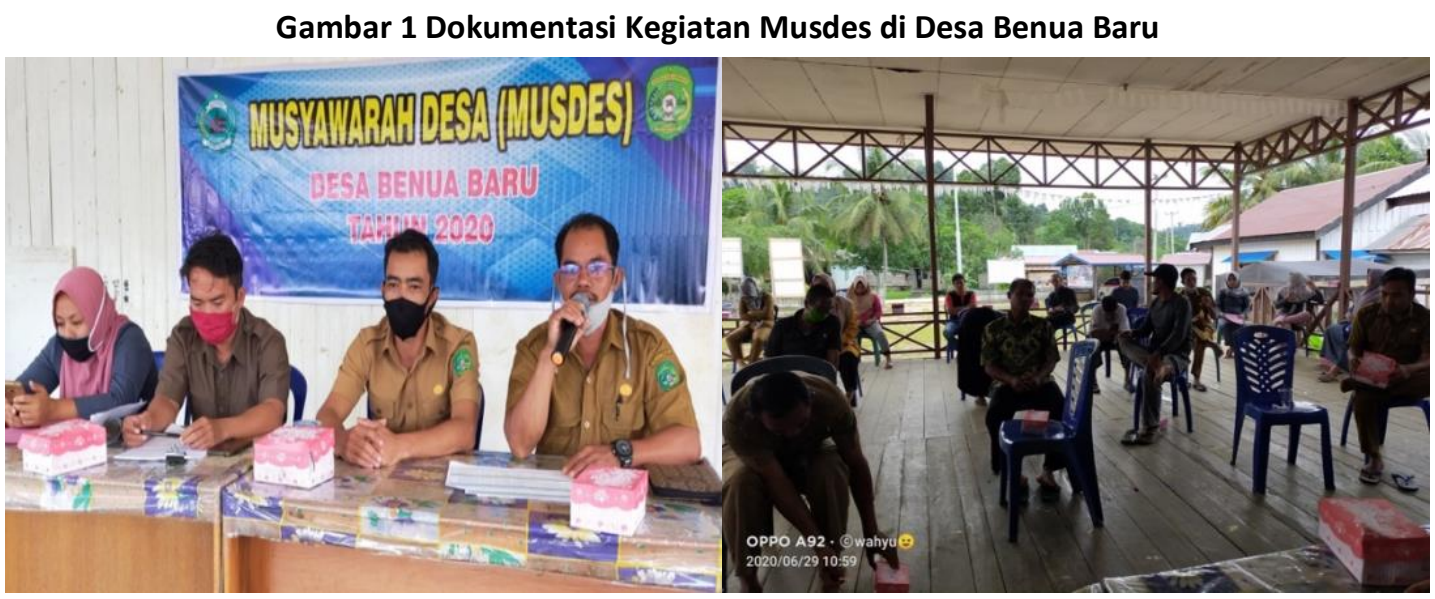

Sumber: Dokumentasi Pemerintah Desa, 2020

Penyesuaian anggaran Dana Desa dalam rangka untuk mendanai program penanggulangan Covid-19 salah satunya melalui pengurangan dana perayaan HUT RI sebesar Rp 20.000.000 menjadi 12.000.000 yang awalnya 32.000.000 dan kegiatan pembangunan infrastruktur lainnya. Dana untuk program penanggulangan Covid-19 
dianggarkan sebesar $\mathrm{Rp} 345.070 .173$ dengan rincian untuk operasional kegiatan relawan desa (posko Covid-19), honor tim Satgas Covid-19 serta akomodasi, sosialisasi hidup bersih dan sehat, pembuatan baleho himbauan covid-19, pengadaan APD desa, sterilisasi fasilitas umum dan fasilitas perkantoran, pengadaan masker melalui gerakan setengah milyar masker untuk desa aman covid-19. Dana yang dianggarkan untuk jaringan pengaman sosial melalui penyaluran BLT DD sebesar Rp 20.700.000 , Penyaluran BLT Dana Desa ditetapkan sebesar Rp 600.000 dibayarkan setiap bulan selama tiga bulan pertama ke 32 KPM, dimulai bulan April, Mei, dan juni. Dan periode berikutnya dianggarkan kembali untuk BLT DD masing-masing masyarakat menerima BLT sebesar Rp. 300.000.

\section{Program Penanggulangan Covid-19 di Desa Benua Baru}

Pemerintah Desa Benua Baru menerapkan beberapa program berdasarkan arahan regulasi dan surat edaran Bupati Kutai Kartanegara dalam pencegahan Covid-19.

1) Pembentukan Tim Satgas Covid-19

Langkah awal yang dilakukan sejak terbitnya Surat Edaran dan arahan Pemerintah Kecamatan adalah pembentukan Tim Satuan Tugas (Satgas) Covid-19 dan pendirian Posko Covid-19. Adapun tugas dari Tim Satuan Tugas (Satgas) Covid-19 adalah 1) Membentuk Posko dan Call Center serta menginformasikan kepada masyarakat; 2) Melakukan penjagaan dan pengamanan yang dilakukan sesuai jadwal pada setiap hari dengan sasaran kerumunan massa; 3) Melakukan koordinasi dan pelaporan kepada Gugus Tugas Kecamatan dan dengan petugas kesehatan setempat apabila menemukan warga masyarakat yang diduga memenui gejala Corona Virus Disease (COVID-19) berdasarkan deteksi suhu tubuh lebih dari 38'C; 4) melakukan sosialisasi tentang pencegahan dan pengendalian serta penanganan penyebaran Corona Virus Disease (COVID-19); 5) Melarang pelaksanaan kegiatan masyarakat yang bersifat mengumpulkan massa dalam jumlah besar termasuk pelaksanaan kegiatan keagamaan dan sejenisnya; 6) Melaporkan segala bentuk kegiatan terkait tugas pada setiap harinya kepada Gugus Tugas Tingkat Kecamatan; 7) Mencatat buku tamu keluar masuk ke Desa; 8) Mendata penduduk rentan sakit, seperti orang tua, balita, serta orang yang memiliki penyakit menahun, penyakit tetap dan penyakit kronis lainnya; dan 9) Ikut melakukan penyemprotan disfektan ke rumah warga dan fasilitas umum dengan Alat Pelindung Diri (APD) yang lengkap. Pemerintah Kecamatan juga aktif melakukan kunjungan ke desa-desa termasuk Desa Benua Baru untuk memantau kegiatan Satgas Covid19 tingkat desa dan Posko Covid-19. 


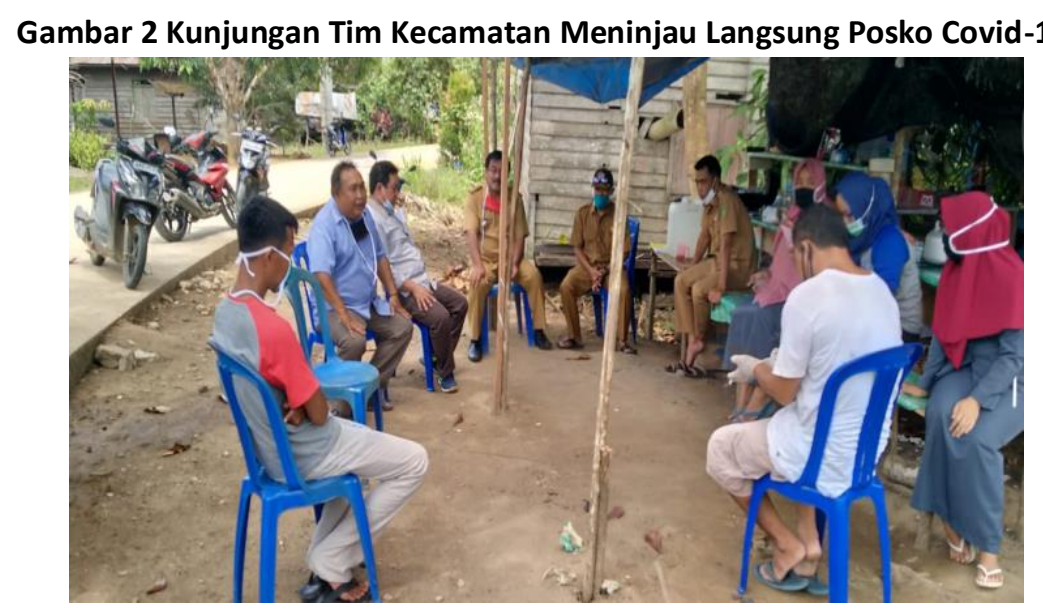

Sumber : Dokumentasi Pemerintah Desa, 2020

2) Pembuatan Ruang Isolasi

Di Desa Benua Baru tidak terdapat ruang isolasi khusus yang disiapkan untuk warga terjangkit covid-19, apabila ada yang terjangkit langsung di rujuk ke tempat isolasi kecamatan. Sejauh ini sosialisasi dilakukan langsung oleh Tim Satgas ke warga maupun melalui sepanduk dan baleho. Dana yang digunakan untuk pembuatan spanduk berasal dari Dana Desa.

3) Pembagian Masker

Gerakan Setengah Miliar Masker untuk Desa Aman Covid-19 yang tertuang pada kebijakan Kementrian Desa PDTT melalui surat Nomor S.2294/HM.01.03/VIII/2020 yang ditujukan kepada seluruh Kepada Desa di Indonesia. Adapun isi surat edaran tersebut adalah mewajibkan Pemerintah Desa melakukan pengadaan masker kain yang dapat dicuci sebanyak empat buah untuk setiap warga, dan pengadaan masker tersebut diadakan dengan Dana Desa melalui BUMDes.

4) Penyemprotan Disinfektan

Penyemprotan disinfektan rutin dilakukan setiap minggunya ke fasilitas umum dan perkantoran yang ada di Desa Benua Baru. Hal ini rutin dilakukan Tim Satgas Covid-19 guna memutus rantai penyebaran Covid-19 di wilayah Desa Benua Baru. Saat ini Desa Benua Baru masih berstatus Zona Hijau dari penyebaran Covid-19. 
Gambar 3 Kegiatan Penyemprotan Disinfektan Ke Fasilitas Umum

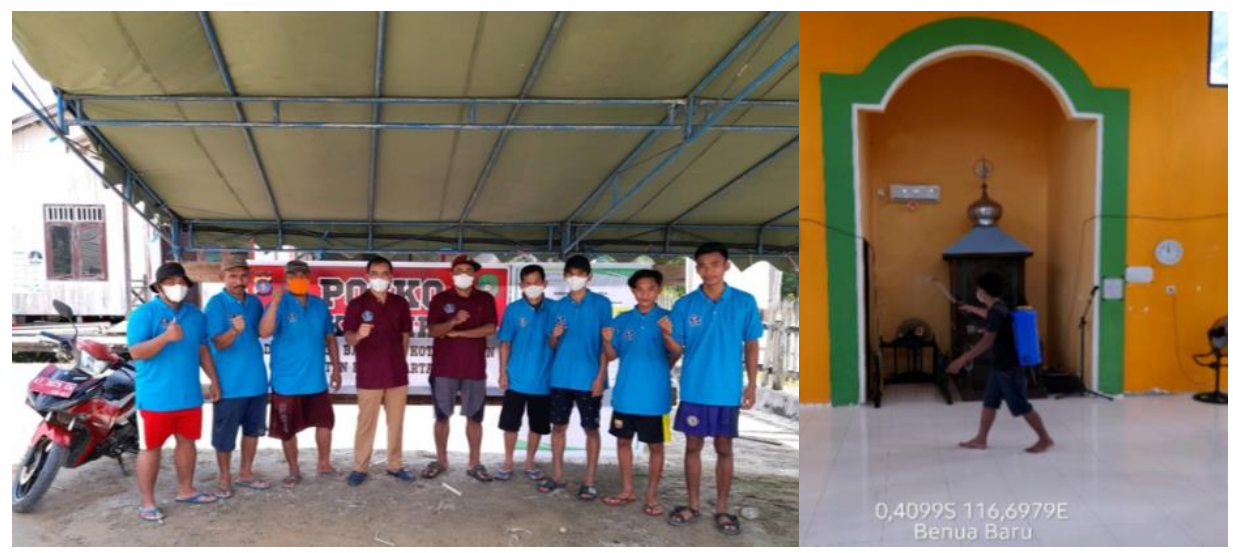

Sumber : Dokumentasi Pemerintah Desa, 2020

5) Penyediaan Handsanitizer dan Hand Soap

Penyediaan Handsanitizer dan Hand Soap disetiap fasilitas umum termasuk tempat ibadah dan perkantoran dalam rangka menjaga Kesehatan dan penyebaran Covid-19. Penganggaran dalam pengadaan Penyediaan Handsanitizer dan Hand Soap menggunakan Dana Desa.

Gambar 4 Penyediaan Handsanitizer dan Hand Soap di Depan Kantor Desa Benua Baru

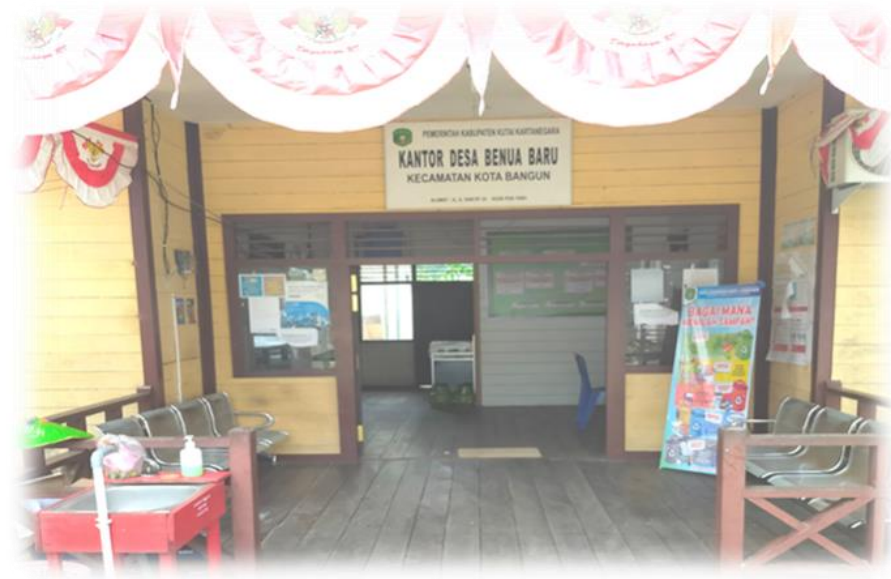

Sumber : Dokumentasi Pemerintah Desa, 2020

6) Bantuan Langsung Tunai (BLT)

Secara rinci kriteria penerima BLT DD diantaranya merupakan keluarga miskin, keluarga yang salah satu anggotanya memiliki Riwayat sakit kronis/menahun, tidak memiliki pekerjaan atau di PHK, dan belum mendapatkan 
bantuan sosial lain. Bantuan Langsung Tunai (BLT) berasal dari Dana Desa yang disalurkan pada bulan April, Mei, Juni dengan besaran Rp 600.000 untuk setiap keluarga penerima manfaat yang telah diputuskan berdasarkan musdes khusus penetapan calon penerima. Di desa Benua Baru berdasarkan berita acara hasil musdes khusus disepakati jumlah penerima manfaat BLT DD sebanyak 32 KPM.

\section{Gambar 5 Pembagian BLT DD ke Warga Penerima}

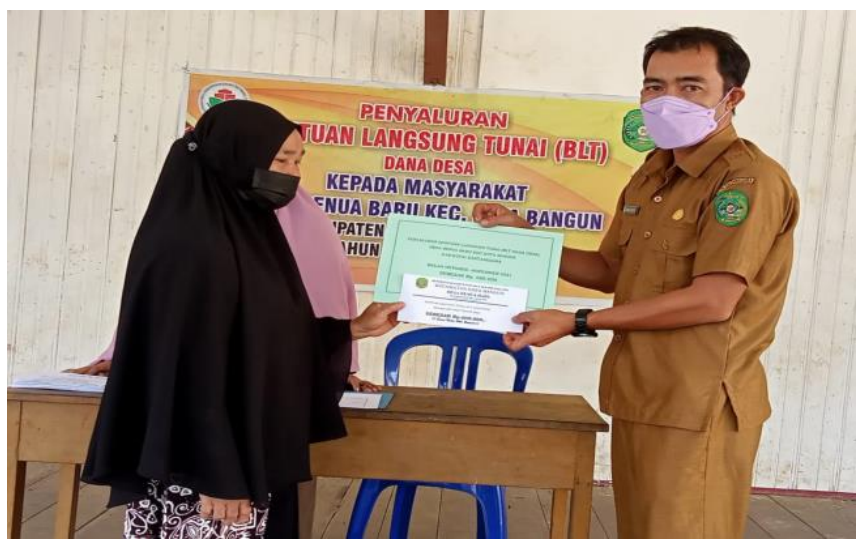

Sumber : Dokumentasi Pemerintah Desa, 2020

\section{E. PENUTUP}

\section{Kesimpulan}

Berdasarkan pemaparan yang telah disampaikan, dapat diambil kesimpulan bahwa dalam proses pergeseran anggaran untuk penanggulangan Covid-19 di Desa Benua Baru tetap melibatkan partisipasi masyarakat melalui penjaringan aspirasi dan musdes, dengan tetap menjalankan protokol kesehatan. Penyesuaian anggaran Dana Desa dalam rangka untuk mendanai program penanggulangan Covid-19 salah satunya melalui pengurangan dana perayaan dan kegiatan pembangunan infrastruktur lainnya yang disesuaikan dengan perioritas kebutuhan. Pemerintah desa Benua Baru menerapkan beberapa program berdasarkan arahan regulasi dan surat edaran Bupati Kutai Kartanegara dalam pencegahan Covid-19, yaitu : 1) Pembentukan Tim Satgas Covid19; 2) Pembuatan Ruang Isolasi; 3) Pembagian Masker; 4) Penyemprotan Disinfektan; 5) Penyediaan Handsanitizer dan Hand Soap; dan 6) Bantuan Langsung Tunai (BLT). 


\section{DAFTAR PUSTAKA}

Republik Indonesia, Keputusan Presiden Nomor 11 Tahun 2020 tentang Penetapan Kedaruratan Kesehatan Masyarakat Corona Virus Disease 2019 (Covid-19).

Republik Indonesia, Keputusan Presiden Nomor 12 Tahun 2020 tentang Penetapan Bencana Nonalam Penyebaran Corona Virus Disease 2019 (Covid-19) Sebagai Bencana Nasional.

Republik Indonesia, Peraturan Pemerintah Pengganti Undang-Undang Republik Indonesia Nomor 1 Tahun 2020 tentang Kebijakan Keuangan Negara dan Stabilitas Sistem Keuangan untuk Penanganan Pandemi Corona Virus Disease 2019 (Covid-19) dan/atau Dalam Rangka Menghadapi Ancaman yang Membahayakan Perekonomian Nasional dan/atau Stabilitas Sistem Keuangan.

Republik Indonesia, Peraturan Menteri Desa, Pembangunan Daerah Tertinggal, Dan Transmigrasi Republik Indonesia Nomor 6 Tahun 2020 tentang Perubahan Atas Peraturan Menteri Desa, Pembangunan Daerah Tertinggal, dan Transmigrasi Nomor 11 Tahun 2019 tentang Prioritas Penggunaan Dana Desa Tahun 2020.

Republik Indonesia, Surat Edaran Menteri Desa, Pembangunan Daerah Tertinggal, Dan Transmigrasi Nomor 8 Tahun 2020 tentang Desa Tanggap Covid-19 dan Penegasan Padat Karya Tunai Desa.

Republik Indonesia, Keputusan Menteri Kesehatan Republik Indonesia Nomor HK.01.07/MENKES/413/2020 tentang Pedoman Pencegahan dan Pengendalian Corona Virus Disease 2019 (Covid-19).

Republik Indonesia, Undang-Undang Republik Indonesia Nomor 6 Tahun 2014 tentang Desa.

Badan Pengawasan Keuangan dan Pembangunan (BPKP). (2015). Petunjuk pelaksanaan bimbingan \& konsultasi pengelolaan keuangan desa. Jakarta: Badan Pengawasan Keuangan dan Pembangunan (BPKP).

Cochran, C. \&. (2005). Public policy: Perspectives and Choices. Boulder, CO: Lynne Rienner Publishers.

Creswell, J. W. (2016). Research design Pendekatan kualitatif, kuantitatif, and Mixed (edisi ketiga). Yogyakarta: Pustaka Pelajar.

Gunawan, I. (2013). Metode penelitian kualitatif. Jakarta: Bumi Aksara.

Junita, N. (2020, Desember 21). Nasional: 10 Peristiwa Penting Covid-19 di Indonesia Tahun 2020. Retrieved from

Kabar24.bisnis.com:https://kabar24.bisnis.com/read/20201221/15/ $1333550 / 10-$ peristiwa-penting-covid-19-di-indonesia-tahun-2020. 
Lele, G. (2016). Pengelolaan konflik dalam kebijakan publik. In A. Subarsono, ed Kebijakan Publik dan Pemerintahan Kolaboratif Isu-isu Kontemporer. Yogyakarta: Gadjah Mada University Press.

Mulyadi. (20001). Sistem perencanaan 7 pengendalian manajemen. Yogyakarta: Aditya Media.

Oberthür, S., \& Groen, L. (2015). The effectiveness dimension of the EU's performance in international institutions: toward a more comprehensive assessment framework. JCMS: journal of common market studies, 1319-1335.

Pasolong, H. (2010). Teori administrasi publik. Bandung: Alfabeta.

Poister. (1998). In W. N. Dunn, Pengantar analisis kebijakan publik. Edisi kedua (p. 429). Yogyakarta: Gadjah Mada University Press.

Rudianto. (2009). Penganggaran. Jakarta: Erlangga. 